DOI: $10.17516 / 1997-1370-0738$

УДК $811.581^{\prime} 42: 330.446 .23$

\title{
A New Approach to Chinese Discourse: Cultural Context
}

\author{
Irina G. Nagibina and Liudmila V. Kulikova* \\ Siberian Federal University \\ Krasnoyarsk, Russian Federation
}

Received 26.01.2021, received in revised form 17.03.2021, accepted 07.04.2021

\begin{abstract}
The article provides a systematic description of the trends in the development of the Chinese discursive and communicative linguistics. Discursive research and its results in the Chinese academic community have their own specifics, which are based on the traditional philosophical and ideological foundation and a unique language picture of the world. The scientific findings explicate culturally determined communicative and discursive conventions of the Chinese social interaction. The aim of the research is to highlight the Chinese cultural discourse studies as a new research tradition in the Chinese linguistics of the modern stage, to expand its methodology, and to construct the discursive space of China as the totality of the dominant cultural and communicative vectors, these vectors being an interpretative tool to help understand and evaluate Chinese discourses.
\end{abstract}

Keywords: Chinese cultural discourse-analysis, deconstruction, transformation, cultural and discursive space, cultural and communicative vector, mode of cultural and communicative vector.

Research area: philology.

Citation: Nagibina, I.G., Kulikova, L.V. (2021). A new approach to Chinese discourse: cultural context. J. Sib. Fed. Univ. Humanit. Soc. Sci., 14(4), 513-521. DOI: 10.17516/1997-1370-0738.

(C) Siberian Federal University. All rights reserved

* Corresponding author E-mail address: irina_nagibina@mail.ru, kulikova_1@list.ru ORCID: 0000-0003-0696-5797 (Nagibina); 0000-0002-1622-8304 (Kulikova) 


\title{
Новый подход к исследованию китайского дискурса: культурный контекст
}

\author{
И.Г. Нагибина, Л.В. Куликова \\ Сибирский федеральный университет \\ Российская Федерачия, Красноярск
}

\begin{abstract}
Аннотация. Статья посвящена систематизирующему описанию тенденций развития дискурсивно-коммуникативного направления в китайском языкознании. Дискурсивные исследования и их результаты в китайском академическом сообществе имеют свою собственную оригинальную специфику, базируются на традиционном философско-мировоззренческом фундаменте и уникальной языковой картине мира, эксплицируя при этом культурно обусловленные коммуникативно-дискурсивные конвенции в социальном взаимодействии носителей китайского языка. Целью исследования стало описание китайского культурологического дискурс-анализа как новой исследовательской традиции в китайской лингвистике современного этапа, расширение его методологии и моделирование дискурсивного пространства Китая в формате доминирующих культурно обусловленных векторов коммуникации как интерпретативной основы дальнейших исследований китайского дискурса.
\end{abstract}

Ключевые слова: китайский культурологический дискурс-анализ, деконструкция, трансформация, культурно-дискурсивное пространство, культурно-коммуникативный вектор, модус культурно-коммуникативного вектора.

Научная специальность: 10.00 .00 - филологические науки.

\section{Introduction}

Since the start of the reforms and opening-up over three decades-ago, Chinese scholars have been involved in the global academic field. Discourse as an interspecific generic concept, the unifying core of which, according to Chen Rudong, is "the interaction of subjects between themselves and the surrounding reality" (Chen, 2008: 131), became the subject of Chinese linguists' study in the late 1980s, since the beginning of external reforms in the country and the integration of Western research concepts into the Chinese humanities. Thus, the basis for the development of discursive problems in Chinese linguistics was formed by the ideas of European authors in the field of discourse theory and discourse analysis, their interpretation by Chinese scholars and attempts to apply appropriate methods on the material of the discursive space of China. During this period the cross-discipline - discourse studies - appeared. Traditionally, Chinese forms of communication have been studied from many perspectives, ranging from text linguistics (话语语言学 / 篇章语言学), conversation analysis (会话分析), pragmatics (语用学), ethnography of communication (民俗交际学), critical discourse analysis (判话语分析), narratology (叙事学), argument theory (论辩), social interactionist theory (互动社会语言学), and discourse psychology (话语心理学) to cross cultural / group / age and interpersonal communication (跨文化, 社群, 代沟, 个性人际交际 研究) (Nagibina, 2017).

However, it should be noticed that the Chinese discourse research traditionally includes literary criticism (文艺学), social communication (传播学), translation studies (翻译学), philosophy (哲学), cultural studies (文化学), politology (政治学), sociology (社会学), historical studies (历史学), commerce studies (商学), jurisprudence (法学), ecology (环境学), theology (宗教学), pedagogics (教育 学), and psychology (心理学).

Linguistic survey of Chinese researchers were conducted on the basis of such famous ar- 
eas as logical-pragmatic communication theory (Gu, 1990; Sheng, 2000); conversation analysis (Yu, 2008; Li, Li, 2014); ethnography of communication (Wen, 2004); the theory of speech acts (Chen, 1996; Yuan, 2004); cognitive theory of the relationship between discourse and grammar (Li, 2000); system-functional gram$\operatorname{mar}(\mathrm{Wu}, 2002)$, and critical discourse analysis (Zhang, 2004; Shi, 2014).

\section{Theoretical framework and description of Chinese cultural discourse studies}

In spite of a number of scholarship on the topic, contemporary Chinese linguistic communication has hardly ever been considered from a Chinese cultural psychological perspective. At the beginning of the $21^{\text {st }}$ century, Chinese cultural approach, namely "Chinese cultural discourse studies" appeared as a part of Chinese discourse studies and cultural discourse studies. To justify his theory the Chinese linguist Shi $\mathrm{Xu}$, the author of this approach, uses the concept and methods of critical discourse studies in general. He regards them as a kind of discourse-analytical procedure aimed to study the way social power abuse, dominance, and inequality are enacted, reproduced, and resisted by text and talk in social and political contexts (Dijk, 1993).

However, there is hitherto little particular and precise knowledge of the relationships between Chinese cultural cognition and emotion, on the one hand, and Chinese discourses, on the other hand, though Chinese cultural psychological principles for social (inter) action have been recognized more generally. Professor Shi $\mathrm{Xu}$ emphasizes: "Human reality is always a cultural reality" (Shi, 2005: 53). At the same time, the concept of "culture" is defined as "a system of perception of reality, symbols, ways of self-expression, values, rules, speech models and social interactions peculiar to a particular civilization" (Shi, 2014: 27). The purpose of cultural discourse studies is to construct another, "alternative" discourse by demonstrating the hidden or, as L.V. Kulikova calls it, "underwater" part of each culture - the place of collision of its own norms, values, and worldviews specific to each nation (Kulikova, 2009: 84).
Thus, cultural discourse studies developed by Shi $\mathrm{Xu}$ for the entire spectrum of Eastern ${ }^{1}$ communication is aimed at interpreting national socio-cultural factors that determine the linguistic forms of utterances, the utterances being traditional for a particular cultural and discursive space. Cultural discourse studies considers any fragment of oral or written discourse as a product of social (inter)action, which is determined by a certain set of communicative orientations of a particular culture. The social context, defined by the cultural orientations of each community, must necessarily be the basis for the research of Eastern communication, implemented through language. Otherwise, the researcher risks to misinterpret the text or oral statement, interpreting patriotism as fanatical nationalism, birth control as a violation of human rights, selective reporting of the current situation as propaganda or outright lies, etc.

The identical traits in historical and economic projections of the discourse of the Eastern countries shows a certain set of similarities of text generation and interpretation (Basso, 1990; Kinge'l, 2000; Shi, 2009, 2013, 2014):

1 . The language of racism faced by the inhabitants of the countries of Asia, Africa, and Latin America at the international level.

2. A general discursive model of utterance construction aimed at harmonizing relations with the interlocutor. To prove its worth Shi $\mathrm{Xu}$ cites the emotional language explicators of “politeness" / 客气 and “faces" / 面子 in Asian countries; shona, or the language of interethnic communication in Zimbabwe, mainly used to restore harmony of communication; "dialogue", which is a characteristic feature of "positive perception of the interlocutor" in discourse.

3. Eastern discourses are characterized by various forms, methods, and a kind of "bindweb" of communication. In Nigeria, for example, silence is an integral part of communication.

4. The main topics of communication in the Eastern countries are the pressing daily issues of poverty, development, peaceful life, etc.

\footnotetext{
Societies of Asia (and the Middle East), Africa, Latin (Central and South) America.
} 
Chinese cultural discourse studies as a component of cultural discourse studies was proposed by Shi $\mathrm{Xu}$ as a reference model for the interpretation of Eastern communication. Scholars of Chinese cultural discourse studies define discourse as the most important component of culture, the spiritual core of which is Chinese philosophy, and insist that Chinese communication should be evaluated taking into account the factor of the manifestation of its own system of knowledge and worldview ideas. According to Chinese scholars, since ancient times, the principles of producing and organizing discourse have been a direct projection of Chinese philosophy (Wei, 1990; Lin, 1994; Ge, 1995; Chen, 2001; Wang, Zheng, 2013; Shi, 2009, 2013, 2014).

It may be noted here that cultural and philosophical categories and principles are wider in scope than their discursive embodiment, since they are appropriated in other forms of social action as well. Chinese discourse studies illustrates the actual functioning of these discursive rules with the examples from various socio-cultural settings.

The Confucian tradition considers communication as the main tool for the formation of society, and its organization should be in harmony with the social order, which implies the achievement of harmony. $\mathrm{Zi} \mathrm{Lu}$, a follower of Confucius, points out in the Analects, the main book of Confucianism:

片言可以折狱 / “A few words can solve a case".

一言可以兴邦 / “One phrase can make a state thrive".

一言而可以丧邦 / “One phrase can bring a state to ruin" (论语原文译文集赏析, Available at: http://down1.5156edu.com/showzipdown. php?id=62967.html). These moral principles are a descriptive, analytic, interpretative, as well as evaluative tool to help understand and criticize more adequately, thus making present-day Chinese discourses more transparent and accountable in current globalization (Shi, 2010). Chinese philosophical postulates, spiritual universals, which have an archetypal nature, act as a "censor" in relation to the participants of the discourse, defining the norms of the national communicative style.
Chinese cultural discourse studies is based on a combination of such methodological components as "deconstruction" and "transformation".

Deconstruction aimed at explicating or revealing "cultural suppression" involves a number of tasks (Shi, 2005, 2009, 2013, 2014):

1. Semantic description of symbols and characters correlated with race, skin color, gender, nationality, ethnicity, colonial history, identity, religion, geographical location, economic situation, etc.

2. Identification of forms and categories of reproduction of the discourse of oppression, which, as a rule, is carried out through the use of a particular cluster, lexical, stylistic, and rhetorical methods combined with the syntactical composition of the text fragments.

3. Direct criticism of the omissions and the implicitness of "cultural dominance" by demonstrating the language structures used for this purpose.

The second structural element of the Chinese cultural discourse analysis, "transformation", is the promotion of discourses that can resist the discourses of "cultural suppression", aimed at leveling the asymmetry and creating a balance of existing discourses. In this regard, transformation includes:

1. Voicing the opinions of the so-called suppressed cultures, commenting on the political and historical reasons for their silence or non-expression of their opinion on a controversial issue that has become a reason for conflict or military actions.

2. Interpretation of communication participants' behavior, which implies constructing the discourse according to cultural and communicative guidelines, a clear comment and explanation of the national cultural characteristics of the behavior of all participants of the polylogue.

3. Creation of a more harmonious communication by changing the discourses of various social institutions in mono- and intercultural interaction.

The study of extensive theoretical and empirical material allowed us to model the Chinese cultural-discursive space through a set of cultural and communicative vectors that char- 
acterize the features of communication and communicative style in the Chinese language culture. The cultural-discursive space is defined in our research as a continuum of the flow of social experience and national traditions, in which a specific content and functional unity is formed on the basis of the integration of cultural and communicative phenomena and symbolic codes.

The cultural and communicative vector is understood as a traditional archetypally determined discursive reference point, which has the social nature of a symbolic convention and a recurrent character, determining the specifics of the linguistic implementation of discourse in a particular linguistic culture. The cultural and communicative vector manifests itself in interaction in various ways, indicated in this paper by the modes of its representation.

The model of the Chinese cultural and discursive space is presented through the combination of eight cultural and communicative vectors and the discursive imperative, the obligatory phono-forming constituent of Chinese communication. The description of the system of cultural and communicative vectors provides a theoretical basis for the analysis of the current Chinese discourse, as well as gives a general idea of the specifics and content of discursive interaction with the representatives of the Chinese language culture. Graphically, the model of the Chinese cultural-discursive space is visualized as follows (Fig. 1).
In the modeling of Chinese cultural and discursive space, the paper highlights the end-to-end constituent of Chinese communication - "Aesthetics of speech" / 话语审美, which determines the speech and behavioral practice of Chinese speakers. The Aesthetics is a discursive imperative that constructs a cultural-discursive background (a set of phonetic, lexical, and syntactic language means), a prerequisite for proper communication. The Aesthetics of speech / 话语审美 as an unwritten law or rule of producing discourse is postulated in "Zhou Yi", the most authoritative work of Chinese canonical and philosophical literature. "Zhou Yi" contains a reference to apriority of beauty and grace of the plane of expression - the totality of material resources of the language as a condition of the translation of the ethical and moral, i.e. achieving the ultimate goal of communication - order and harmony:

《君子进德修业, 忠信所以进德也, 修辞立 其诚, 所以居业也》(周易传文白话解, Available at: http://vdisk.weibo.com/s/ujpgg77s55hYt. $\mathrm{html})$. In its modern interpretation this provision means "A noble man should approach the choice of the form of implementation of the plan with the utmost responsibility and reverence". Within the framework of the Chinese language culture, the aesthetics of discourse is a twoway process of satisfying the needs of aesthetic thinking of both the referent and the recipient of the message (Shi, 2010). As described by the

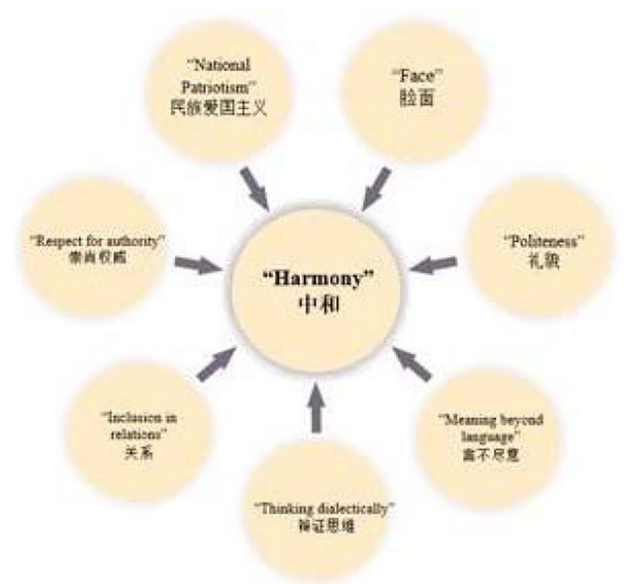

Fig. 1 
literary critic Liu Xie in "Dragon-Carving and the Literary Mind", a classical book of literary criticism, the Chinese aesthetics of communication is extremely associated with the state of “xujing" / 虚静 - the enlightened and immune to external factors consciousness (the state of the spiritual world), which allows the author as a producer of discourse to embody the artistic concept, setting and delineating the boundaries of the aesthetics of the work (Yang, 2003).

The aesthetics of Chinese discourse as a tool for proper interaction of members of society is a kind of philosophical and religious dogma of successful communication. Zuo Qiuming, a historian of Lu Kingdom, the supposed author of "Zuo Zhuan", in the comments to the chronicle of Spring and Autumn Period, specifies:

言之无文，行而不远 / “Non-elegant words will not spread far" (周易传文白话解, Available at: http://vdisk.weibo.com/s/ujpgg 77s55hYt.html).

The scale of the consequences of what has been said can be predicted depending on the type of discourse. According to Yang $\mathrm{Na}$, the words of Confucius 名不正, 则言不顺; 言不 顺, 则事不成 / “(If) the name is not corrected, then the word does not correspond (with the deed); the word does not correspond, then the deed will not be done" imply the direction of all actions to "improve and resystematize the language" in order to give it more euphony, which will positively affect harmonious social interaction (Yang, 2014: 258).

The cultural and communicative vector "Harmony" as the goal-setting constituent of the Chinese cultural and discursive space is the central element in the model of Chinese cultural discourse studies to construct and maintain the balance between individuals, microgroups, societies, and states. Within the framework of the paper, seven modes of implementation of the "Harmony" vector at the discursive-behavioral level are identified. The inner feeling of harmony occurs under the condition of the ability to conduct natural communication according to such principles as 和顺、平和、心平气 和、和颜 悦色 / "peacefulness, self-restraint, equilibrium, kindness”, “、融洽 / “agreement and harmony”, 和解、和平、结束战争或争执 / "compromise, reconciliation, the end of the war or dispute" (Li, 1988).

The cultural and communicative vector "Face" / 脸面, which goes back to the ethical and political tradition of Confucianism, determines the social and normative behavior in the Chinese culture. The Chinese cultural and discursive space is constructed by the twelve modes of this vector in the order of interpersonal / intergroup / interstate interaction formed under the influence of moral constraints. For example, the following fragment of Chinese political discourse implements the mode "saving a face" / 留脸面, which, as a rule, appears more frequently than the discursive variants “injury to a face" / 损脸面 or "cast aside all considerations of face" / 撕破脸面:

卫亚非表示对欧盟的提议非常失望，希望 欧盟部长会议能认真对待此事，给予中国企 业一个公正的裁决 / "Wei Yafei is deeply disappointed with the proposal of the European Union, but hopes that the Council of Ministers of the European Union can make a fair decision" (Shi, 2010: 154).

At the same time, the mode "saving a face" / 留脸面 is implemented by a complex oppositive sentence with the inclusion of the combinations 公公的的 (“fair decision"), 认 真对待 (“take seriously, responsibly") and the modal verb 能 (“can”).

The cultural and communicative vector "Politeness" / 礼貌 is realized in the interdependence or hierarchical relations between the participants of communication, determined by the communicative context. The vector "Politeness" / 礼貌 is a communicative convention that manifests itself in self-humiliation, belittling one's position, and elevating the interlocutor.

The cultural and communicative vector “Meaning beyond language" / 言不尽意 is one of the central and most practical elements in the Chinese belief system. It is that of the nature of language. That is, language can never express meaning entirely; one must use language carefully or strategically and go beyond language in searching of meaning. The Chinese belief about the relationship between language and meaning can also be traced back to the Chinese classic philosophy-that regards language 
as limited in its power. Yet, meaning is boundless and requires endless search. The value of implicit information in the Chinese language is primarily based on the intellectual effort that the addressee has already expended to obtain it. The extraction of implicit meanings for native Chinese speakers is commensurate with the deciphering of sacred, canonical texts that can only be understood by a select few, in this case, those involved in the Chinese cultural and discursive space. For this reason, the level of language proficiency is largely determined by the knowledge of cheng'yu, the knowledge of historical and mythological characters, because allusions to them are peculiar for all types of discourse.

This vector specifies the independent decoding of the information by the addressee. It has three modes of implementation: "speaking sparingly or little" / 慎言, "speaking implicitly, indirectly or vaguely" / 含蓄 and "multiple repetition of thought" as a way of producing the true meaning of the utterance / 正义多表. The mode "speaking implicitly, indirectly or vaguely" / 含蓄 is a discursive construction of meanings through allusion and metaphor, when the addressee is forced to read between the lines and make his own conclusions from what is said, to interpret it in his/her own way.

The forms of production and understanding of the Chinese discourse, typified by such situations as disasters, emergencies, crises, as well as the presentation of one's own achievements, occur according to the cultural and communicative vector "Thinking dialectically" / 辩证思维. The implementation of this vector is carried out by the modes of maximum restriction of the use of extreme terms or statements; global description of the discursive context; inclusion of the positive aspects of the current negative situation, and vice versa the mode "being vigilant in peacetime" / 居 安思危.

The cultural and communicative vector "Inclusion in relations" / 关系 reflects the same primacy of the addressee and the addressee in the construction of discourse, which is always a dialogical form of communication. In accordance with the Confucian tradition, the implementation of this vector is considered in three modes: "relations between the family and the state" / 家国关系, “relations between officials and the common people" / 官民关系, “relations between ordinary people" / 民民关系.

One of the variants of the implementation of the ancient principle of regulating the ethical norms of social behavior 孝道 / "loyalty (service) to parents, or the norms (principle) of filial piety" is the cultural and communicative vector “Respect for authority” / 崇尚权威. The orientation of communication according to this vector is manifested through explicit indication of the relevant social position, age, experience; quoting authoritative statements; excessive frequency (in comparison with non-Chinese discourse) of referring to an authoritative person's opinion.

The cultural and communicative vector “National patriotism” / 民族爱国主义 is manifested in many types of the Chinese discourse. In modern China, this vector is realized in “soft" / 软实力, implicit opposition to two opponents - Japan and the United States. This reference point is especially found in the Chinese political leaders' oratory, where various types of positive self-presentation are used: a politician's speech on behalf of the government, the speech on behalf of the country, and the speech on his/her own behalf. The cultural and communicative vector "National patriotism" is actively represented in the Chinese Internet space, in information blogs posted by users in social networks and forums. Such maxims or fragments of them, as well as the quotes from the texts of the discourse of the top leadership of the Communist Party of China are immediately borrowed by other users of the Internet network. Many expressions have become precedent statements and aphorisms.

\section{Conclusion}

Having assimilated foreign concepts and methods of discourse analysis, it is at the beginning of the $21^{\text {st }}$ century when the Chinese linguistic community proposed its own theory of interpretation of Eastern discourses in general and the Chinese communication in particular - cultural discourse studies and its investigation line, Chinese cultural discourse studies. 
Based on the study of extensive theoretical and empirical material, the paper models the Chinese cultural and discursive space through a set of cultural and communicative vectors and their complex philosophical and linguistic description. This expands the methodology of Chinese cultural discourse studies as a device and resource for making sense of especially practical cultural discourses.

In this paper we attempt to highlight the cultural and communicative vectors, discursive modes or embodiments of the basic com- ponents of the Chinese communication. The proposed model of the Chinese cultural-discursive space has a complex and verifiable character, since it is based on research carried out in the tradition of Chinese cultural discourse studies.

The authors' model of interpretive analysis of the Chinese discursive space can create a productive perspective for further study of various types of the Chinese institutional communication, as well as discursive practices of everyday Chinese interaction.

\section{References}

Basso, E.B. (1990). Native Latin American cultures through their discourse. Bloomington, Folklore Institute, Indiana University, 304 p.

Dijk, van T.A. (1993). Elite discourse and racism. London, Sage Publications, 320 p.

Gu, Y-g. (1990). Politeness phenomena in modern Chinese. In Pragmatics, 14, 237-257.

Chen, G-m. (2001). Towards transcultural understanding: A harmony theory of Chinese communication. In Transculture: perspectives on cross-cultural relations, 55-70.

Chen, R. (1996). Food-paying and Chinese Politeness. In Journal of Asian Pacific Communication, 7, $143-155$.

Chen, R. (2008). Status quo and trends in discourse analysis. In Journal of Zhejiang University, 6, $130-137$.

Ge, L. (1995). On the question of Psychological Culture-Analysis of the Cross-Cultural Space of China and foreign countries. Dalian, Publishing House of Liaoning Normal University Liaoning normal publishing house, $195 \mathrm{p}$.

Kinge'l, K. (2000). Language development research in $21^{\text {st }}$ century Africa. In African Studies Quarte$l y, 3$. Available at: http://web.africa.ufl.edu/asq/v3/v3i3a3.htm

Kulikova, L.V. (2009). Kommunikativnyi stil'v mezhkul'turnom obshchenii: monografiia [Communicative style in cross-cultural communication: monograph]. Moscow, Flinta, Nauka, $286 \mathrm{p}$.

Li, H., Li, J. (2014). Conversational Discourse-Online business transaction analysis. Beijing, Publishing House of Literature on the Defense Industry, $130 \mathrm{p}$.

Li, Z. (1988). Chinese culture theory. Guangzhou, Sun Yatsen University Press, 330 p.

Li, Zh. (2000). Text linguistics in the modern Chinese language. Available at: http://162.105.138.200/ uhtbin $/$ cgisirsi $/ \mathrm{x} / 0 / 0 / 5$ ? searchdatal $={ }^{\wedge} \mathrm{C} 70990 . \mathrm{html}$

Lin, Y. (1994). The Chinese. My country and my people. Beijing: People's Literature Publishing House, $280 \mathrm{p}$.

Nagibina, I.G. (2017). Formirovanie diskursivno-kommunicativnoi paradigmy v kitaiskom iazykoznanii: ot teorii $k$ sotsial'noi praktike: dis...kand. filol. nauk [Formation of discursive-communicative paradigm in the Chinese linguistics: from theory to social practice: PhD thesis]. Krasnoyarsk, $232 \mathrm{p}$.

Sheng, X. (2000). Fundamentals and principles of discourse: an aspect of pragmatics. Available at: http://vdisk.weibo.com/s/uxb_aaFQ1wsNJ?sudaref=www.baidu.com

Shi, G. (2014). Critical Discourse-Analysis of court hearings. Beijing, Science Press, 320 p.

Shi, X. (2005). A cultural approach to discourse. New York, Basingstoke, 223 p.

Shi, X. (2009). Reconstructing eastern paradigms of discourse studies. In Journal of Multicultural Discourses, 4, 29-48.

Shi, X. (2013). Discourse and culture: From discourse analysis to cultural discourse studies. Shanghai, Shanghai Foreign Language Education Press, 420 p. 
Shi, X. (2014). Chinese Discourse Studies. Basingstoke: Palgrave Macmillan, 223 p.

Wang, F., Zheng, H. (2013). Chinese cultural psychology. Guangzhou: Jinan University Press, 622 p.

Wei, Zh. (1990). Confucianism and Modern China. Shanghai, Shanghai People's publishing house, $410 \mathrm{p}$.

Wen, X. (2004). A study of the Pragmatics of the Discourse of irony. Beijing, Chinese Public Publishing House, $180 \mathrm{p}$.

Wu, Q. (2002). The Structure of Chinese Discourse. Changsha: Yuelu Book Club, 324 p.

Yang, G. (2003). Dragon-Carving and the Literary Mind. Beijing, Foreign Language Teaching Press, $460 \mathrm{p}$.

Yang, N. (2014). Cultural discourse studies of women's rights discourse: analysis, strategies and principles. Hangzhou: Hangzhou University Press, 386 p.

Yu, G. (2008). Conversational discourse analysis. Shanghai, Education Press, 255 p.

Yuan, T. (2004). Introduction to the traditional system of Chinese addresses. Beijing, Chinese Book Publishing, $147 \mathrm{p}$.

Zhang, J. (2004). Critical Discourse-Analysis of court hearings. Guanzhou, Guangdong University of Foreign Studies, $358 \mathrm{p}$.

Zhang, J. (2004). Values and Being: Reflections on the Discourse of Values. Beijing, China Social Science Press, 244 p. 